\author{
Asian Journal of \\ Medical and Biological Research \\ ISSN 2411-4472 (Print) 2412-5571 (Online) \\ www.ebupress.com/journal/ajmbr
}

\title{
Article \\ Effect of seed washing either alone or in combination with garlic extract and Knowin 50WP on quality of jute seeds
}

\author{
M. S. Islam and M. S. Monjil* \\ Department of Plant Pathology, Bangladesh Agricultural University, Mymensingh-2202, Bangladesh \\ *Corresponding author: Dr. M. S. Monjil, Department of Plant Pathology, Bangladesh Agricultural University, \\ Mymensingh-2202, Bangladesh. E-mail: smonjil@yahoo.com
}

Received: 07 June 2016/Accepted: 23 June 2016/ Published: 30 June 2016

\begin{abstract}
Efficacy of seed washing, garlic extract, prewashed seeds treated with garlic extract, Knowin 50 WP (Carbendazim) and prewashed seeds treated with Knowin 50WP were evaluated on seed borne fungi of jute seeds. Nine seed borne fungi were detected on both deshi and tossa jute seed samples collected from sadar upazilla of Barisal district viz., Macrophomina phaseolina, Botryodiplodia theobromae, Fusarium spp, Colletotrichum corchori, Curvularia lunata, Aspergillus flavus, A. niger, Penicillium spp. and Alternaria spp.. Physical seed washing and garlic extract were found effective against seed borne diseases of jute which significantly decrease the association of seed borne fungi from jute seeds. Prewashed seeds treated with garlic extract showed highest germination and highest reduction of seed borne mycoflora from desi and tossa jute seeds. Knowin 50WP or prewashed seeds treated with Knowin 50WP were found effective to reduce seed borne fungi from jute seeds. Highest vigor index was obtained in jute seedlings raised from prewashed seeds treated with Garlic or Knowin 50WP. Thus, prewashed seeds treated with Garlic or Knowin 50WP resulting significant reduction of seed-borne fungal population and enhancing seeding vigor.
\end{abstract}

Keywords: jute; seed borne fungi; seed washing; garlic; Knowin 50WP

\section{Introduction}

Jute is an important cash crop in Bangladesh and India, which together accounts for about $84 \%$ of world production of jute fibre (BJRI, 2008). The land and climatic condition of Bangladesh is very suitable for the production of quality jute. Like other crops, diseases of jute play a vital role in decreasing the quality and yield of fibre. Biswash et al. (1992) reported eighteen diseases of jute caused by fungi, nematode and virus. Fakir (2000) reported 10 seed borne diseases of jute in Bangladesh. There are about 10\% production loss of jute may be incurred annually due to seed-borne fungal diseases in Bangladesh (Nitul, 2009). Begum (1989) found that Colletotrichum corchori, Botryodiplodia theobromae and Macrophomina phaseolina caused germination failure and seed rot of jute leading to develop diseased symptoms on growing seedlings.

It is unquestionable that proper disease control measures should be taken for the production of quality jute seeds. Proper disease control measures can substantially improve the quality of jute and significantly increase the fiber yield. Among the practices used, seed treatment is probably the cheapest and safest method of direct plant disease control. Seed treatment, generally with a combination of selective fungicides, is a standard practice for control of the seedling disease complex (Minton and Garber, 1983). Physical seed cleaning is important practice for reducing pathogens associated with seeds. Hasan (2000) reported that physical seed sorting of rice seeds resulted $8.33 \%$ germination increase over non-sorting seeds. It is published that seed cleaning, washing and seed treatment reduce disease incidence in seedlings (Asad-ud-doullah et al., 2002). However, effective seed treatments are needed to effectively reduce the seed-borne inoculum. Nowadays, it is reported that combination of physical and chemical or other non-chemical seed treatment are more effective against seed borne fungi than use of single chemical or other non-chemical treatment (Mallick et al., 2013, Uzzal et al., 
2014). Islam et al. (2013) reported that physical seed washing with water followed by seed treatment with plant extract or chemical fungicides resulting significant reduction of seed-borne fungal population and enhancing seeding vigor in mesta seeds. Considering the above facts the present research work was undertaken aiming to know the efficacy of seed washing either alone or in combination with garlic and Knowin 50WP in reducing the incidence of fungi associated with jute seeds.

\section{Materials and Methods}

Farmer's stored seeds of deshi jute, BJC-7370 (Corchorus capsularis) and tossa jute, O-9897 (C. olitorius) were collected from sadar upazilla of Barisal district. The seeds were then kept in brown paper bags and stored in the refrigerator at $4 \mathrm{oC}$ in Seed Pathology Center (BAU) until use. The experiment was conducted at Seed Pathology Center (SPC) and M.S. Laboratory, Department of Plant Pathology, Bangladesh Agricultural University (BAU), Mymensingh. Total six treatments were applied for the experiment which were $\mathrm{T} 0=\mathrm{Control}, \mathrm{T} 1=$ Seed washing with normal water, T2= Garlic extract (1:1), T3= Prewashed seeds treated with garlic extract $(1: 1), \mathrm{T} 4=$ Knowin 50 WP (Carbendazim) @ 0.2\% and T5= Prewashed seeds treated with Knowin 50 WP @ 0.2\%. Garlic extract was prepared by using the method described by Hossain et al. (1997). Seed washing was done following the method of Islam et al. (2013). After washing, seeds were placed in open air for drying (4-5 h). Seed treatment with garlic extracts was done by dipping seeds in freshly prepared garlic extracts (1:1) for 20 minutes. Chemical fungicide, Knowin $50 \mathrm{WP}$ was tested as a seed treating chemical. Five grams of seeds from both samples and $.01 \mathrm{~g}$ of Knowin $50 \mathrm{WP}$ were taken in two different $250 \mathrm{ml}$ of Erlenmeyer flask and were shaken for $10 \mathrm{~min}$ for proper coating. The treated and untreated seeds were tested for seed-borne fungi following the standard blotter method (ISTA, 1999). Four replications were conducted for each sample. After incubations, the germination of seeds and yielded fungi were counted. The incubated seeds were observed individually under stereomicroscope and the associated fungi were detected by observing their growth characters on the incubated seeds on blotter paper following the keys outlined by Khan and Islam (1975). For proper identification of fungi, temporary slides were prepared from the fungal colony, observed under a compound microscope, and identified.

For germination and vigor tests, seeds were sown in tray soil. Watering was done to maintain soil moisture. Trays were kept in green house for protecting young and delicate seedling from heavy shower and scorching sunlight. After 10 days of sowing, seed germination, seedling shoot length and root length were measured for calculating seedling vigor (vigor index) following the formula given by Baki and Anderson (1972). All data were analyzed and mean differences among the treatments were compared by Duncan's Multiple Range Test (DMRT). A statistical computer package MSTAT-C was used for analyzing the data.

\section{Results}

Effect of different treatments on germination of seeds and seed borne fungi of deshi and tossa jute was recorded by using standard blotter methods (Table 1 and 2). In case of deshi jute, germination of seeds significantly varied in different treatments ranged from 56.00 to $94.67 \%$. The lowest germination $(56.00 \%)$ of seeds was found in untreated (T0) seeds and the highest $(94.67 \%)$ germination was found on prewashed seeds treated with Knowin 50WP (Table 1). Plating of seeds in wet blotter yielded total nine different fungi from all the samples examined. These fungi were Macrophomina phaseolina, Botryodiplodia theobromae, Fusarium spp., Colletotrichum corchori, Curvularia lunata, Aspergillus flavus, A. niger, Penicillium spp. and Alternaria spp..

Among the six different treatments, seed treatment with garlic extract (T2), prewashed seeds treated with garlic extract (T3), Knowin 50WP (T4) and prewashed seeds treated with Knowin 50WP (T5) showed enhanced performance for reducing seed born fungal population from seeds. Association of C. corchori, M. phaseolina, B. theobromae, A. niger, Penicillium spp. and Alternaria spp. was completely eradicated in case of prewashed seeds treated with garlic extract (T3) and prewashed seeds treated with Knowin 50WP (T5). Total seed borne fungi were lowest in prewashed seeds treated with Knowin 50WP, while the second best performance was recorded by the treatment with prewashed seeds treated with garlic extract. Treatment with garlic extract and Knowin 50 WP also showed better performance for inhibiting fungal population from seeds.

In case of tossa jute, germination of seeds significantly varied in different treatments ranged from 58.66 to $96.00 \%$ (Table 2). The lowest germination $(58.66 \%$ ) of seeds was found in untreated (T0) seeds and the highest (96.007\%) germination was found on prewashed seeds treated with garlic extract (T3) and prewashed seeds treated with Knowin 50WP @ 0.2 (T5). Plating of seeds of tossa jute in wet blotter yielded total nine different fungi from all the samples examined which were similar to deshi jute. Among the six different treatments, seed treatment with garlic extract (T2) or prewashed seeds treated with garlic extract (T3) or prewashed seeds treated with Knowin 50WP (T5) showed enhanced performance in controlling C. corchori, M. phaseolina and B. theobromae. Complete eradication of these three seed borne fungi was observed with T3 and T5. Seed washing 
(T1) was found effective to control all of the detected seed borne fungal flora. Association of C. corchori, M. phaseolina, B. theobromae, C. lunata, A. niger, Penicillium spp. and Alternaria spp. with seeds was completely eradicated in prewashed seeds treated with garlic extract (T3) or prewashed seeds treated with Knowin 50WP (T5). Complete eradication of Fusarium spp. were not achieved by any treatment but lowest seed borne infection of Fusarium spp. was observed by prewashed seeds treated with Knowin 50WP (T5).

Effect of different treatments on seed germination in tray soil was recorded (Fig.1). Highest germination $(82.00 \%)$ of deshi jute seed samples was observed in T5 (prewashed seeds treated with Knowin 50WP, whereas lowest germination $(70.00 \%$ ) was observed $\mathrm{T} 0$ (control). In case of tossa jute seed samples highest germination (77.00\%) was observed in T5 (prewashed seeds treated with Knowin 50 WP, whereas lowest germination was found in prewashed seeds (T1) and it was $71.00 \%$. In deshi jute seeds, higher shoot length $(5.48 \mathrm{~cm})$ was observed in Knowin 50WP (T4) as well as in prewashed seeds treated with Knowin 50WP (T5) whereas lowest shoot length was observed in T0 (control). Higher root length $(3.72 \mathrm{~cm}$ ) was observed in prewashed seeds treated with garlic extract (T3) whereas lowest root length was observed in T0 $(2.88 \mathrm{~cm})$. After calculation, highest vigor index (736.36) was found in prewashed seeds treated with Knowin 50 WP (T5) and lowest vigor index was found in T0 (581.00). In case of tossa jute seeds, highest shoot length was observed in prewashed seeds treated with garlic extract $(\mathrm{T} 3=5.54 \mathrm{~cm})$ whereas lowest shoot length was observed in $\mathrm{T} 0(3.66 \mathrm{~cm})$. Highest root length was observed in prewashed seeds treated with Knowin 50 WP $(\mathrm{T} 5=2.88 \mathrm{~cm})$ whereas lowest root length was observed in T0 (3.14). Highest vigor index was found in prewashed seeds treated with Knowin $50 \mathrm{WP}(\mathrm{T} 5=632.94)$ and lowest vigor index was found in T0 (496.40).

\section{Discussion}

Seed-borne fungi are one of the major factors of low yield of jute fiber. Therefore, it has a great impact on jute crop production and thus, the prevention of these fungi is important. In present research program, the seed-borne fungi associated with the jute seeds were investigated as well as some control measures were studied. Prevalence of nine most seed-borne fungi was detected with seeds of jute samples collected from sadar upazilla of Barisal district. Different workers studied the fungal flora associated with the jute seeds in Bangladesh and reported that Macrophomina phaseolina, Botryodiplodia theobromae, Colletotrichum corchori, Curvularia lunata, Fusarium spp. and Aspergillus spp. were found to be associated with the jute seeds (Begum, 1989; Fakir et al., 1990; Haider et al., 1992, Islam, 2013).

Seed treatment is considered as a primary and effective method for controlling seed borne fungi. It is expected to be a natural phenomenon that the percent of seed germination would be higher in case of treated seeds than that of untreated seeds. Similarly, many workers found the similar results when they treated the different crop seeds with different fungicides (Wahid et al. 1995 and Das and Narian, 1996). Reduced incidence of seed-borne fungi was recorded in treated seed samples of jute seeds. Garlic extract was found effective against seed borne diseases of jute. From the present experiment, it is appeared that garlic had antifungal activity. Garlic extract was effective against Macrophomina phaseolina, Botryodiplodia theobromae, Colletotrichum corchori and Fusarium spp. (Dubey and Dwivedi, 1991, Khan and Kumar, 1992 and Rahman et al., 1999). Sultana et al. (2007) reported that garlic paste increased the rate of germination and decrease the rate of post emergence seedling mortality of jute.

Physical seed washing is a good method for reducing fungal mycoflora from seeds (Uzzal et al. 2014). Combination of physical seed washing and other chemical or plant extract treatment is to be an effective way to control seed borne fungi. In the present study, prewashed seeds treated with garlic extract showed highest germination and highest reduction of seed borne mycoflora. Kabir et al. (2007) reported that farmer's stored wheat seeds washed with water or brine solution increase seed germination and suppressed the incidence of Bipolaris sorokiniana. Panna et al. (2009) reported reduced fungal association in seeds washed with brine solution. Reduced number of seed borne fungi were detected in prewashed mesta seeds treated with garlic extract (Islam et al., 2013). In the experiment, Knowin 50WP or prewashed seeds treated with Knowin 50WP were found effective to reduce seed borne fungi from jute seeds. Thus, combined treatment of water washing and garlic extract or Knowin 50 WP significantly reduced the associated fungi from jute seeds.

In deshi and tossa jute seeds, higher vigor indexes were obtained in jute seedlings raised from prewashed seeds treated with Garlic or Knowin 50WP (Table 3). Roy et al. (2011) reported the quality improvement of jute seed by plant extracts viz. garlic tablet, allamanda tablet, neem leaf extract, bishkatali leaf extract and zinger rhizome extract, and observed a significant increase in seedling vigor over untreated control after garlic treatment. 
Table 1. Effect of different treatments on germination and seed-borne fungi of deshi jute.

\begin{tabular}{|c|c|c|c|c|c|c|c|c|c|c|}
\hline Treatmens & $\begin{array}{l}\text { Germination } \\
(\%)\end{array}$ & $\begin{array}{l}\text { Colletotrichum } \\
\text { corchori }\end{array}$ & $\begin{array}{l}\text { Macrophomina } \\
\text { phaseolina }\end{array}$ & $\begin{array}{l}\text { Botryodiplodia } \\
\text { theobromae }\end{array}$ & $\begin{array}{l}\text { Fusarium } \\
\text { spp }\end{array}$ & $\begin{array}{l}\text { Curvularia } \\
\text { lunata }\end{array}$ & $\begin{array}{l}\text { Aspergillus } \\
\text { flavus }\end{array}$ & A. niger & $\begin{array}{l}\text { Penicillium } \\
\text { spp }\end{array}$ & $\begin{array}{l}\text { Alternaria } \\
\text { spp }\end{array}$ \\
\hline $\mathrm{T}_{0}$ & $56.00 \mathrm{e}$ & $12.00 \mathrm{a}$ & $12.00 \mathrm{a}$ & $12.00 \mathrm{a}$ & $12.00 \mathrm{a}$ & $32.00 \mathrm{a}$ & $24.00 \mathrm{a}$ & $8.00 \mathrm{a}$ & $6.00 \mathrm{a}$ & 0.00 \\
\hline $\mathrm{T}_{1}$ & $77.33 \mathrm{~d}$ & $8.00 \mathrm{~b}$ & $8.00 \mathrm{~b}$ & $8.00 \mathrm{~b}$ & $4.00 \mathrm{~b}$ & $28.00 \mathrm{~b}$ & $16.00 \mathrm{~b}$ & $4.00 \mathrm{~b}$ & $4.00 \mathrm{~b}$ & 0.00 \\
\hline $\mathrm{T}_{2}$ & $81.33 \mathrm{c}$ & $8.00 \mathrm{~b}$ & $4.00 \mathrm{c}$ & $4.00 \mathrm{c}$ & $0.00 \mathrm{c}$ & $24.00 \mathrm{c}$ & $4.00 \mathrm{c}$ & $0.00 \mathrm{c}$ & $4.00 \mathrm{~b}$ & 0.00 \\
\hline $\mathrm{T}_{3}$ & $90.64 \mathrm{~b}$ & $0.00 \mathrm{c}$ & $0.00 \mathrm{~d}$ & $0.00 \mathrm{~d}$ & $0.00 \mathrm{c}$ & $20.00 \mathrm{~d}$ & $4.00 \mathrm{c}$ & $0.00 \mathrm{c}$ & $0.00 \mathrm{c}$ & 0.00 \\
\hline $\mathrm{T}_{4}$ & $82.67 \mathrm{c}$ & $0.00 \mathrm{c}$ & $4.00 \mathrm{c}$ & $0.00 \mathrm{~d}$ & $0.00 \mathrm{c}$ & $8.00 \mathrm{e}$ & $0.00 \mathrm{~d}$ & $0.00 \mathrm{c}$ & $4.00 \mathrm{~b}$ & 0.00 \\
\hline $\mathrm{T}_{5}$ & $94.67 \mathrm{a}$ & $0.00 \mathrm{c}$ & $0.00 \mathrm{~d}$ & $0.00 \mathrm{~d}$ & $0.00 \mathrm{c}$ & $8.00 \mathrm{e}$ & $0.00 \mathrm{~d}$ & $0.00 \mathrm{c}$ & $0.00 \mathrm{c}$ & 0.00 \\
\hline $\mathrm{LSD}_{0.05}$ & 1.78 & 0.81 & 1.10 & 0.43 & 0.66 & 1.53 & 1.06 & 0.178 & 0.79 & 0.00 \\
\hline
\end{tabular}

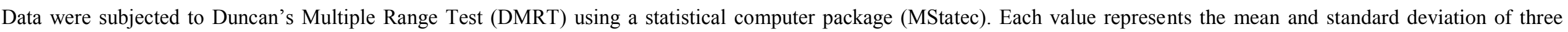

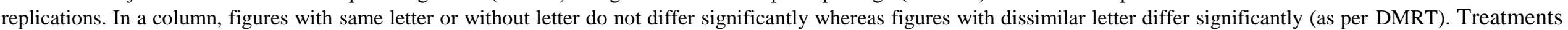

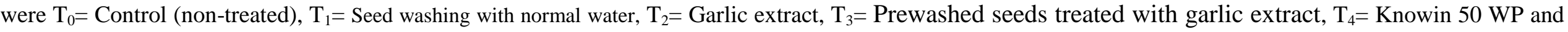
$\mathrm{T}_{5}=$ prewashed seeds treated with Knowin 50WP.

Table 2. Effect of different treatments on germination and seed-borne fungi of tossa jute.

\begin{tabular}{|c|c|c|c|c|c|c|c|c|c|c|}
\hline \multirow[b]{2}{*}{ Treatments } & \multirow[b]{2}{*}{$\begin{array}{l}\text { Germination } \\
(\%)\end{array}$} & \multicolumn{9}{|c|}{ \% seed-borne infection } \\
\hline & & $\begin{array}{l}\text { Colletotrichum } \\
\text { corchori }\end{array}$ & $\begin{array}{l}\text { Macrophomina } \\
\text { phaseolina }\end{array}$ & $\begin{array}{l}\text { Botryodiplodia } \\
\text { theobromae }\end{array}$ & $\begin{array}{l}\text { Fusarium } \\
\text { spp }\end{array}$ & $\begin{array}{l}\text { Curvularia } \\
\text { lunata }\end{array}$ & $\begin{array}{l}\text { Aspergillus } \\
\text { flavus }\end{array}$ & $\begin{array}{l}\text { Aspergillus } \\
\text { niger }\end{array}$ & $\begin{array}{l}\text { Penicillium } \\
\text { spp }\end{array}$ & $\begin{array}{l}\text { Alternaria } \\
\text { spp }\end{array}$ \\
\hline $\mathrm{T}_{0}$ & $58.66 \mathrm{~d}$ & $32.00 \mathrm{a}$ & $10.00 \mathrm{a}$ & $8.00 \mathrm{a}$ & $64.00 \mathrm{a}$ & $12.00 \mathrm{a}$ & $16.00 \mathrm{a}$ & $8.00 \mathrm{a}$ & $6.00 \mathrm{a}$ & $8.00 \mathrm{a}$ \\
\hline $\mathrm{T}_{1}$ & $80.00 \mathrm{c}$ & $4.00 \mathrm{~b}$ & $6.00 \mathrm{~b}$ & $0.00 \mathrm{c}$ & $20.00 \mathrm{~d}$ & $12.00 \mathrm{a}$ & $12.00 \mathrm{~b}$ & $8.00 \mathrm{a}$ & $4.00 \mathrm{~b}$ & $4.00 \mathrm{~b}$ \\
\hline $\mathrm{T}_{2}$ & $80.00 \mathrm{c}$ & $0.00 \mathrm{c}$ & $0.00 \mathrm{~d}$ & $4.00 \mathrm{~b}$ & $32.00 \mathrm{~b}$ & $8.00 \mathrm{~b}$ & $8.00 \mathrm{c}$ & $4.00 \mathrm{~b}$ & $0.00 \mathrm{c}$ & $0.00 \mathrm{c}$ \\
\hline $\mathrm{T}_{3}$ & $96.00 \mathrm{a}$ & $0.00 \mathrm{c}$ & $0.00 \mathrm{~d}$ & $0.00 \mathrm{c}$ & $24.00 \mathrm{c}$ & $0.00 \mathrm{c}$ & $4.00 \mathrm{~d}$ & $0.00 \mathrm{c}$ & $0.00 \mathrm{c}$ & $0.00 \mathrm{c}$ \\
\hline $\mathrm{T}_{4}$ & $90.00 \mathrm{~b}$ & $0.00 \mathrm{c}$ & $4.00 \mathrm{c}$ & $0.00 \mathrm{c}$ & $20.00 \mathrm{~d}$ & $0.00 \mathrm{c}$ & $4.00 \mathrm{~d}$ & $4.00 \mathrm{~b}$ & $0.00 \mathrm{c}$ & $0.00 \mathrm{c}$ \\
\hline $\mathrm{T}_{5}$ & $96.00 \mathrm{a}$ & $0.00 \mathrm{c}$ & $0.00 \mathrm{~d}$ & $0.00 \mathrm{c}$ & $4.00 \mathrm{e}$ & $0.00 \mathrm{c}$ & $0.00 \mathrm{e}$ & $0.00 \mathrm{c}$ & $0.00 \mathrm{c}$ & $0.00 \mathrm{c}$ \\
\hline $\mathrm{LSD}_{0.05}$ & 2.52 & 0.73 & 0.66 & 0.16 & 1.31 & 0.51 & 0.49 & 0.21 & 0.32 & 0.28 \\
\hline
\end{tabular}

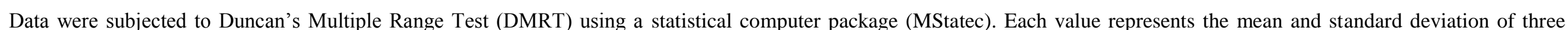

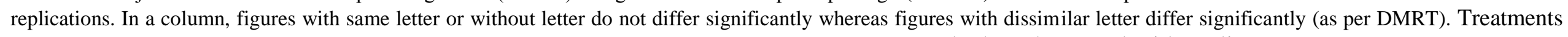

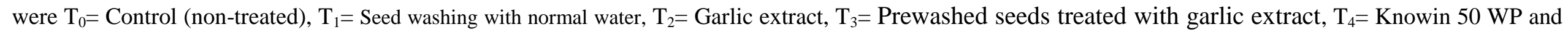
$\mathrm{T}_{5}=$ prewashed seeds treated with Knowin 50WP. 


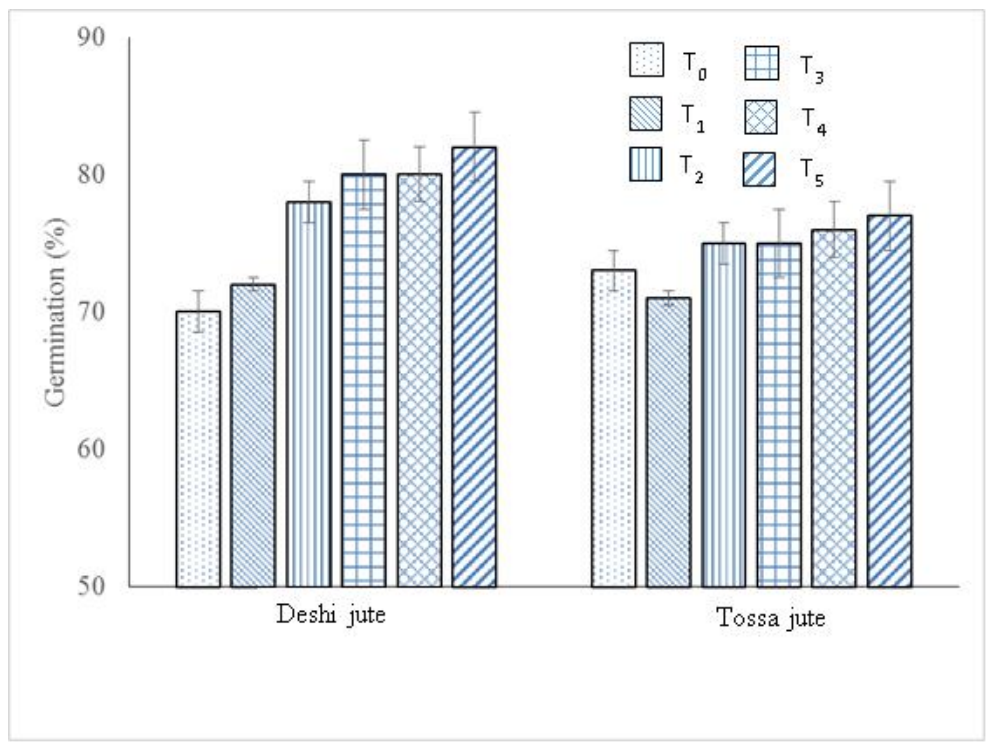

Figure 1. Effect of different treatments on seed germination (tray sand methods). Each value represents the mean and standard deviation of three replicates. Treatments were $T_{0}=$ Control (non-treated), $T_{1}=$ Seed washing with normal water, $T_{2}=$ Garlic extract, $T_{3}=$ Prewashed seeds treated with garlic extract, $T_{4}=$ Knowin 50 $\mathrm{WP}$ and $\mathrm{T}_{5}=$ prewashed seeds treated with Knowin 50WP.

Table 3. Effect of different treatments on mean shoot length, mean root length and vigor index of deshi jute.

\begin{tabular}{lllllll}
\hline Treatments & \multicolumn{3}{c}{ Deshi } & \multicolumn{2}{c}{ Tossa } \\
\cline { 2 - 7 } & $\begin{array}{l}\text { Shoot length } \\
(\mathbf{c m})\end{array}$ & $\begin{array}{l}\text { Root length } \\
(\mathbf{c m})\end{array}$ & Vigor index & $\begin{array}{l}\text { Shoot length } \\
(\mathbf{c m})\end{array}$ & $\begin{array}{l}\text { Root length } \\
(\mathbf{c m})\end{array}$ & Vigor index \\
\hline $\mathrm{T}_{0}$ & $5.42 \mathrm{a}$ & $2.88 \mathrm{c}$ & $581.00 \mathrm{e}$ & $3.66 \mathrm{~d}$ & $3.14 \mathrm{a}$ & $496.40 \mathrm{e}$ \\
$\mathrm{T}_{1}$ & $5.36 \mathrm{a}$ & $3.08 \mathrm{c}$ & $607.68 \mathrm{~d}$ & $4.94 \mathrm{c}$ & $2.40 \mathrm{~d}$ & $521.14 \mathrm{~d}$ \\
$\mathrm{~T}_{2}$ & $5.34 \mathrm{a}$ & $3.38 \mathrm{~b}$ & $680.16 \mathrm{c}$ & $5.20 \mathrm{bc}$ & $2.72 \mathrm{c}$ & $594.00 \mathrm{c}$ \\
$\mathrm{T}_{3}$ & $5.16 \mathrm{~b}$ & $3.72 \mathrm{a}$ & $710.40 \mathrm{~b}$ & $5.54 \mathrm{a}$ & $2.60 \mathrm{c}$ & $610.50 \mathrm{~b}$ \\
$\mathrm{~T}_{4}$ & $5.48 \mathrm{a}$ & $3.42 \mathrm{~b}$ & $712.00 \mathrm{~b}$ & $5.30 \mathrm{ab}$ & $2.74 \mathrm{bc}$ & $611.04 \mathrm{~b}$ \\
$\mathrm{~T}_{5}$ & $5.48 \mathrm{a}$ & $3.50 \mathrm{ab}$ & $736.36 \mathrm{a}$ & $5.34 \mathrm{ab}$ & $2.88 \mathrm{~b}$ & $632.94 \mathrm{a}$ \\
$\mathrm{LSD}_{0.05}$ & 0.14 & 0.225 & 12.07 & 0.29 & 0.15 & 6.46 \\
\hline
\end{tabular}

Data were subjected to Duncan's Multiple Range Test (DMRT) using a statistical computer package (MStatec). Each value represents the mean and standard deviation of three replications. Columns with same letters do not differ significantly whereas dissimilar letters differ significantly (as per DMRT). Treatments were $\mathrm{T}_{0}=$ Control (non-treated), $\mathrm{T}_{1}=$ Seed washing with normal water, $\mathrm{T}_{2}=$ Garlic extract, $\mathrm{T}_{3}=$ Prewashed seeds treated with garlic extract, $\mathrm{T}_{4}=$ Knowin $50 \mathrm{WP}$ and $\mathrm{T}_{5}=$ prewashed seeds treated with Knowin 50WP.

\section{Conclusions}

From this study, it can be concluded that seed-borne fungi of jute seeds affect seed germination and seedling vigor as well as prewashed seeds treated with garlic extract or chemical can be an effective way to decrease seed borne fungi of jute seeds.

\section{Conflict of interest}

None to declare.

\section{References}

Asad-ud-doullah M, MK Anam, M Nazrul Islam, M Rahman, GA Fakir and I Hossain, 2002. Effect of seed cleaning, washing and seed treatment on seedling disease incidence and yield of Rice. Pak. J. Biol. Sci., 5: 767-769.

Baki AA and JD Anderson, 1972. Physiological \& biological deterioration of seeds. In seed Biology, Vol. 11. Academic Press, Newyork. pp. 283-315. 
Baxter CD, 1960. The control of jute pests and diseases in British Guiana. Tropical Science, 2. 1-2.

Begum LA, 1989. Evaluation of different seed health testing techniques for detection of major seed-borne fungal pathogens of jute. M. Sc. Ag. Thesis, Dept. of Plant Pathology, Bangladesh Agricultural University, Mymensingh, Bangladesh. pp. 98.

Biswas AC, K Sultana, HA Begum, S Iqbal and AKM Farukuzzaman, 1992. Diseases of kenaf (Hibiscus canabinus) and mesta (Hibiscus sabdariffa) recorded in Bangladesh. Bangladesh J. Jute Fibre Res., 17: 103109.

BJRI, 2008. Hand book of Agricultural Technologies of Jute, Kenaf and Mesta crops, Bangladesh Jute Research Institute, Manikmia Avenue, Dhaka. pp. 01-04.

Das SK and A Narian, 1996. Effect of selected fungicides on seed-borne fungi and percentage of germination of diseased seeds of crops. Dept. of P1ant Pathology, Orissa University of Agriculture and Technology. 11: 207-211.

Dubey RC and RS Dwivedi, 1991. Fungitoxic properties of some plant extracts against vegetative growth and sclerotial viability of Macrophomina phaseolina. Indian Phytopath., 44: 411-413.

Fakir GA, 2000. List of seed borne diseases of important crops occurring in Bangladesh. Seed Pathology Laboratory, Dept Plant Path. BAU, Mymensingh, pp. 7-8

Fakir GA, MR Islam and MF Islam, 1990. Survey on the health status of jute and rice seeds of farmers of Sadar Thana, Mymensingh, Proc. BAU Res. Prog., 4:42-47.

Haider MR, Begum J and NM Anwar,1992. Mycoflora associated with jute seeds collected from five districts of Bangladesh. Chittagong University D tud:, Part 11, 16: 61-69.

Hasan MM, 2000. Effect of seed cleaning and washing on germination disease incidence and yield of rice BR 11 (mukta). M.Sc. Thesis, Department of Plant Pathology, BAU, Mymensingh, Bangladesh.

Islam M, 2013. Diseases of Jute, Kenaf \& Mesta and Their Management, Bangladesh Jute Research Institute, Manikmia Avenue, Dhaka-1207.

Islam MS, MSI Uzzal1, K Mallick and MS Monjil, 2013. Management of seed mycoflora of mesta (Hibiscus sabdariffa) by seed washing, garlic extract and Knowin. Progress. Agric., 24: 1-7.

ISTA (International Seed Testing Association). 1999. International Rules for Seed Testing, International Seed Testing Association, Seed Sci. \& Technol, Zurich, Switzerland. pp. 13-15.

Kabir MH, FM Aminuzzaman, MR Islam and MSM Chowdhury, 2007. Effect of physical and chemical seed treatments on leaf spot (Bipolaris sorokiniana) and yield of wheat. World J. Agric.Sci., 3: 306-315.

Khan AZM and NAS Islam 1975. Colletotrichum lindeinuthianum of Dolichos lablab from Bangladesh. Bangladesh J. Bot., 4: 121-123.

Khan MI and R Kumar, 1992. Antifungal activity of leaf extract of Neem on seed mycoflora of wheat. Indian J. Seed Abs., 15: 299

Mallick K, MS Islam, MSI Uzzal and MS Monjil, 2013. Evaluation of water wash, garlic extract and Knowin 50 WP for controlling seed-borne fungi from cucumber seeds. Bangladesh J. Crop Science, 25: 37-42.

Minton EB and RH Garber, 1983. Controlling the seedling disease complex of cotton. Plant Disease, 67:115118.

Nitul R, 2009. Health and Quality of Jute Seed Samples Collected from Rajoir Upazilla of Madaripur District and their Management by Plant Extracts, MS thesis, Department of Plant Pathology, BAU, Mymensingh, Bangladesh. pp. 42-43.

Panna R, Aminuzzaman FM, Islam MR, Bhuyan MHMB 2009. Evaluation of some physical seed treatments against Bipolaris sorokiniana associated with wheat seeds. Int. J. Sustain. Crop Prod., 4: 40-41.

Rahman GMM, MR Islam and MA Wadud, 1999. Seed treatment with plant extracts and hot water: a potential biophysical method of controlling seed-borne infection of wheat. Bangladesh J. Training and Development, 12:185-190.

Roy KK, MMR Khan, MM Hossain and MAR Khokon, 2011. Feasibility of quality improvement of jute seed by plant extracts. Progress. Agric., 22: 1-10.

Sultana K, SMA Haque, H Banu, HQM Mosaddeque and MS Polan. 2007. Study on Transmission of Seed Borne Fungal Pathogens of Jute (Corchorus Capsularis) at Different Rate of Seed Infections. G-Science Publication, 3: 46-49.

Uzzal MSI , MS Islam, K Mallik and MS Monjil, 2014. Efficacy of seed washing with water and treatment with garlic extract and Carbendazim for reducing seed-borne pathogens from rice variety Kalijira. Progress. Agric., 24: 45-51.

Wahid A, MS Javed and M Idress, 1995. Chemical control of Fusarium root-rot, wilt and cotton rot of soybean (Glycine max L.). Pak. J. Phytopath. 7: 21-24. 